\title{
A CASE DISCUSSION ON EFFECT OF PALASHA KSHARA SUTRA IN THE MANAGEMENT OF BHAGANDARA [FISTULA-IN-ANO] WITH SPECIAL REFERENCE TO ITS ANTIMICROBIAL EFFECT
}

\section{Case report}

\author{
Mahesh Kumar E.S ${ }^{1 *}$, Hemantha Kumar $\mathbf{P}^{2}$ \\ 1. Asst Professor, 2. Professor \& HOD \\ Department of PG Studies in ShalyaTantra, \\ S.D.M.College of Ayurveda \& Hospital, Hassan, Karnataka.
}

\begin{abstract}
Kshara Karma is a one of the parasurgical procedure in Ayurveda. In this study Palasha Kshara Sutra is used in Bhagandara (Fistula-in-ano ). Though, Apamarga Kshara Sutra is highly effective in the management of Fistula-in-ano. But pain, irritation, difficulty in preparation has limited its use. Thus, various type of Kshara Sutra tried with their efficacy in different angle. In this present study effort will be made to define the probable mode of action of Palasha Kshara sutra in Fistula-in-Ano. This is equally effective with less pain and easy to prepare because a single plant is enough and not a seasonal plant. A $50 \mathrm{yr}$ old male presented with complaints of painful swelling with pus discharge in the anal region since 3 days has been presented here.
\end{abstract}

Key Words: Kshara, Palasha, Bhagandara

\section{Introduction:}

Fistula-in-ano is one of the most common ailment pertaining to ano-rectal region. This disease causes discomfort and pain to patient, which creates problems in routine work. In modern medical science, the description of Fistula is available long back from time of Hippocrates 6 B.C. But in Ayurvedic classical texts Fistula-in-Ano has been widely described as name of Bhagandara along with treatment, before the time of Hippocrates. There we found Bhagandara also treated by Kshara sutra. It is a medicated thread, which is prepared by repeated coating of various medicinal

\footnotetext{
*Corresponding Author:

Mahesh Kumar E.S,

Asstant Professor,

Dept. of PG Studies in Shalya Tantra,

SDMCA \& H, Hassan. 573201

E-mail: machia_a@yahoo.co.in
}

plants over the thread. In 1964, a scientific study was carried out in the dept. of Shalya-Shalakya, IMS, BHU, Varanasi .The procedure of applying Kshara Sutra is very easy, in most of the cases and it was done under local anaesthesia and only few cases require spinal anesthesia. Changing of Kshara sutra was done by railload method i.e. the new medicated Kshara sutra was tied to the end of the previous Kshara sutra, this sutra is cut and pulled out thorough fistulous opening and new one placed in position. The cutting rate of fistulous tract was recorded by measuring the length of Kshara sutra on subsequent changing.

\section{Case report:}

A 50 yr old male presented with complaints of painful swelling with pus discharge in the anal region since 3 , days , six month ago patient was asymptomatic, one day he noticed painful swelling in the 
anal region associated with fever and consulted local physician, took treatment .Swelling got reduced by rupture with pus discharge. A similar episode occurred after two months and got relieved by same way of treatment. There is no history of $\mathrm{DM} / \mathrm{HTN}$, the family history was not suggestive of same complaint to other member. On local Examination there was a painful swelling of $2 \times 2 \mathrm{~cm}$ associated with single opening with pus discharge in the left ischiorectalfossa at four ${ }^{\circ}$ clock position. On Digital Rectal Examination there was normal sphincter tonicity. On Proctoscopy - no abnormality was detected .The classical Lakshanas of Bhagandara like pidaka of pakwa or apakwa in Guda region (1), goodamoola ,ruk, jwara(2) etc were observed. Routine hematology investigations (TC, DC, Hb, ESR, RBS) and urine investigations were within normal limits. As Susrutha describred Kshara sutra is indicated in Bhagandara (3).Under spinal Anaesthesia, First the patient is kept in proper lithotomy position and perianal region was cleaned with antiseptic lotions and draped. Then gloved index finger was gently introduced into the rectum. Then a suitable selected probe was passed through the external opening of fistula. The tip of the probe was forwarded along the path of least resistance and was guided by the finger in rectum to reach in to the lumen of anal canal through the internal opening and its tip was finally directed to come out of anal orifice. The pus filled cavity at the external opening is drained by incision and drainage.Then a suitable length of plain thread or Palasha -kshara sutra was taken and threaded into the eye of probe. There after the probe was pulled out through the anal orifice, to leave the thread behind in the fistulous track. The two ends of the Plain thread were then tied together with a moderate tightness outside the anal canal. This procedure is called primary threading and on second day of post-operative day the Palasha-kshara sutra application is done. The Palasha -kshara sutra was changed at weekly interval. Before changing of ksharasutra, on weekly interval, pus smear was sent for culture in Mac-Conkey's agar medium. Initial length of the Fistula track is of Ten centimeter, pus smear taken before operative procedure suggestive of growth of organism E coli, after one week no growth seen in the swab culture report, like in second week, third week etc, except fourth week swab culture report suggestive of staphylococcus aureus, this may be due to contamination from outside as the area known for contamination but patient was asymptomatic by the effect of kshara sutra-in-situ. The unit cutting time i.e total days taken to cut through the tract divided by initial length of the tract in centimeter i.e 77 days divided by $10 \mathrm{~cm}$, so palasha kshara sutra in this patient took 7.7 days for cutting one centimeter of fistula tract.

\section{Discussion on the effect of treatment:}

Mode of Action of Kshara sutra in Fistula in Ano:

By application of kshara sutra it does cutting layer by layer and there is continuous drainage of fistulous track which helps in healing. The medicaments which are used to prepare the thread will dissolute the fistulous tissue of the track (Debridement by the Ksharana process) and stimulates the healthy granulation tissue for healing.

\section{Conclusion:}

There was a marked reduction of symptoms to pain, irritation, inflammation, burning sensation and local reactions in treated group as compared to control group. Availability, Collection problems have been trespassed by the present method. Economical, minimised the problems of preparation and application of Kshara sutra therapy. No recurrence of case reported during the last 6 months of follow up. So Palasha-kshara sutra can be considered as a better alternative in place 
of Apamarga kshara sutra because it has more acceptability, easily available.

\section{References:}

1. Vaidya Yadavji Trikamjiacharya: Sushruta samhitha with Dalhanacharya Nibhandhasangraha and Gayadasacharya Nyaychandrika Panjika commentary edited by Chaukhamba Sanskrit sansthan, Varanasi, Reprint 2012, Nidanasthana $4^{\text {th }}$ chapter, Page -270 .
2. Vaidya Yadavji Trikamjiacharya: Sushruta samhitha with Dalhanacharya Nibhandhasangraha and Gayadasacharya Nyaychandrika Panjika commentary edited by Chaukhamba Sanskrit sansthan, Varanasi, Reprint 2012, Chikitsasthana 17/32, Page - 468 .

3. Hemantha Kumar, P. : Role of Aragvadhadi Sutra in the Management of Bhagandara, M.S.(Ayu.) thesis, I.M.S., B.H.U. (1996).

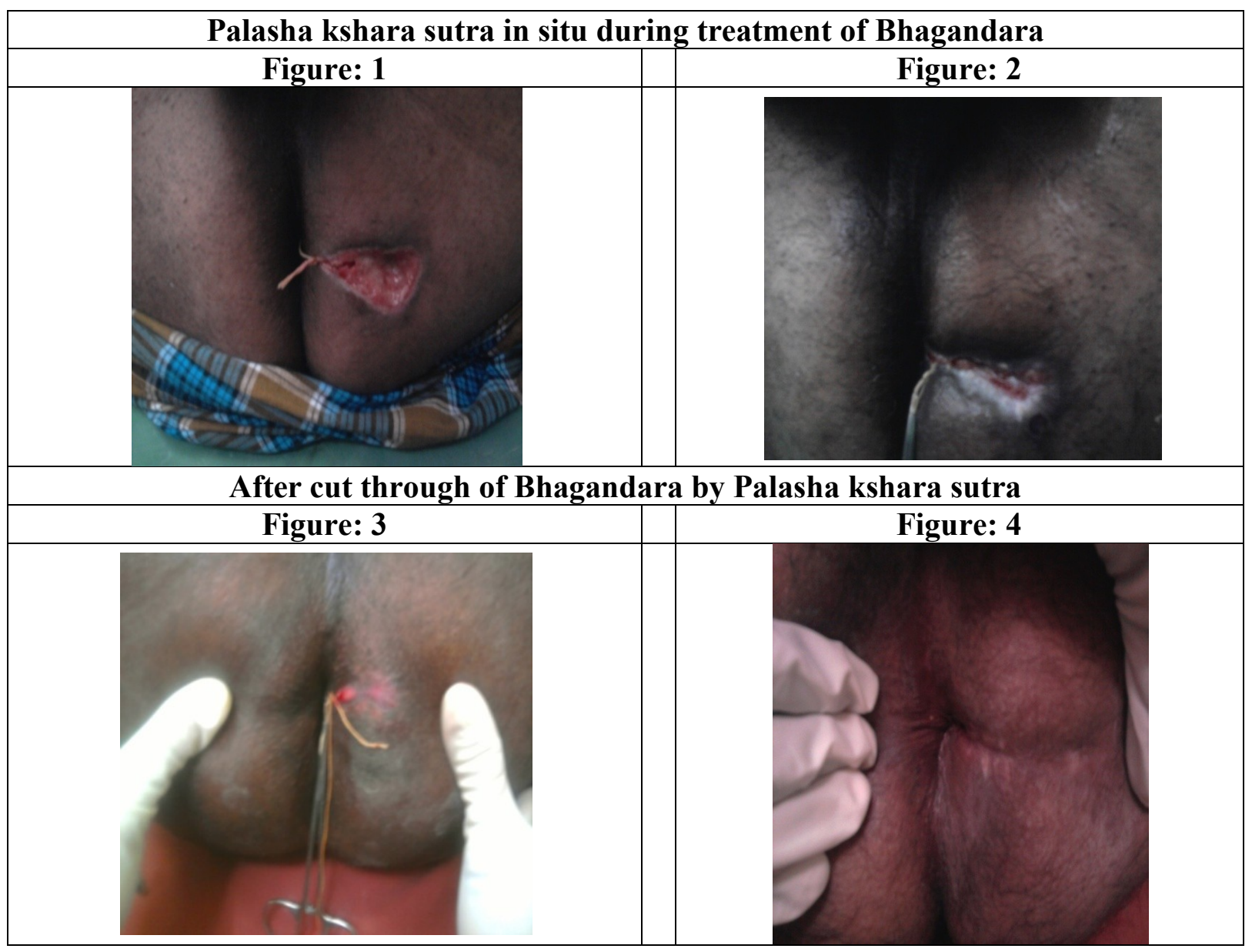

